\title{
The Measurement of Bacterial Viabilities by Slide Culture
}

\author{
By J. R. POSTGATE, JANET E. CRUMPTON AND J. R. HUNTER \\ Microbiological Research Establishment, Porton, Wiltshire
}

(Received 28 May 1960)

\begin{abstract}
SUMMARY
A procedure is described for measuring the viabilities (\% viable/total organisms) of populations of Aerobacter aerogenes by short-term incubation on agar films followed by differential counting under the microscope. The only special apparatus needed is a supply of metal annuli. The procedure estimates viability with $95 \%$ fiducial limits of $\pm 9 \%$; it appears applicable to other aerobic bacteria, to yeasts and to spore suspensions.
\end{abstract}

\section{INTRODUCTION}

The viability of a microbial population may be defined pragmatically as the proportion of its members that are capable of multiplication when provided with optimal conditions for growth. In this usage an organism may be called dead if it does not multiply in those conditions, and certain philosophical difficulties in the concept of death as applied to micro-organisms (see, for example, Valentine \& Bradfield, 1954; Powell, 1956) may be avoided. Many procedures are available for determining the viability in this sense, the most popular being that of obtaining simultaneous total and viable counts on the population. Other procedures include 'vital staining', based on the assumption that death is accompanied by an altered permeability to dyes, which has been used with yeasts (e.g. Townsend \& Lindegren, 1953) and bacteria (e.g. Knaysi, 1935; Knaysi \& Ford, 1938; White, 1947). Strugger (1948) modified this technique by using a fluorescent dye with preparations of soil bacteria and Razumovskaya \& Osipova (1958) applied Strugger's method to pure cultures of Acetobacter spp. Techniques based on the belief that death is associated with inability to reduce a redox dye such as a tetrazolium have been reported (e.g. Greenberg, Eidus \& Diena, 1958). Koch (1959) assumed that leakage of labelled purines from populations of labelled bacteria measured the extent of death in such populations. Barer, Ross \& Tkaczyk (1953) proposed that immersion refractometry should distinguish dead from living cells since their refractive indices were often different; this technique was used by Firkhman (1959). Mager, Kuczynski, Schatzberg \& Avi-dor (1956) showed that populations of live Gram-negative bacteria had a greater optical density in solutions than in distilled water, but that dead ones did not, and suggested the exploitation of this 'optical effect' for viability determination. Wade \& Morgan (1954) developed a staining procedure which made use of the accumulation of ribonucleic acid that takes place before a viable organism divides; Valentine \& Bradfield (1954) measured viability by incubating populations in $\mathbf{3} \%$ urea, which permitted growth but not division, and determined the ratio of giant to ordinary cells with an electron microscope. Powell (1956) grew bacteria on a cellophan grid and determined the ratio of the individual count before incubation 
to the group count after incubation; Taubeneck $(1957,1959)$ proposed modifications of Powell's procedure for slide cultures.

A critique of the methods available is not appropriate to the present paper, but their existence and the fact that none is widely accepted as both satisfactory and convenient perhaps justifies the publication of yet another one. The procedure reported below is a modification of the slide culture used by Knöll (1944) and others. The cellophan or Formvar grids needed for Powell's procedure or Taubeneck's modification are dispensed with; the method requires no special apparatus beyond microscope slides, metal annuli and a microscope set up for phase contrast or dark ground illumination. It has proved satisfactory as a routine procedure for studying the viability of microbial populations, provided these fall in the range $5-100 \%$.

\section{METHODS}

Preparation of agar cultures on slides. Brass annuli of $20 \mathrm{~mm}$. internal diameter, $22 \mathrm{~m}$. external diameter and $1 \mathrm{~mm}$. depth were cut from piping; these support circular coverslips (nominally $\frac{7}{8} \mathrm{in}$., actually less) without overlap. They were cleaned, chemically blackened to facilitate observation of the sealing operation (below) and stored in $98 \%(\mathrm{w} / \mathrm{v})$ ethanol in water ready for use. Clean microscope slides 0.8-1 mm. thick were kept in ethanol, and before use both were burned dry and the annulus placed on the slide. A $0.22-0.24 \mathrm{ml}$. portion of hot agar medium (see below) was spread inside the annulus, thus sticking it to the glass, and the whole was stood under a Petri plate lid for $5 \mathrm{~min}$. A portion of the population to be studied was diluted to $c \mathbf{1 0 0}$ million organisms $/ \mathrm{ml}$., spread on the surface of the agar film and allowed to stand for $10 \mathrm{~min}$. If the surface of the agar was not dry by then, excess fluid was wiped off with a piece of clean filter paper.

A clean coverslip kept in ethanol was wiped with a cloth and placed on the annulus over the agar. The annulus-coverslip interface was touched with a loop of distilled water and capillarity caused water to flow between the two surfaces, thus sealing the agar under an air space. In spite of evaporation of the distilled water, the seal remained effective for many hours. The slide was incubated at a suitable temperature and for an appropriate period (37 ${ }^{\circ}$ and 2-4 hr. with populations of Aerobacter aerogenes) cooled and inspected under phase contrast either after cooling to room temperature or after storage for up to $18 \mathrm{hr}$. at $4^{\circ}$. Two stages in the preparation of these slides are illustrated in $\mathrm{Pl} .1$.

Preparation of agar. Commercial agar preparations and broths brewed from butchers' meat frequently contain solid debris and dead bacteria, both of which interfere with counts. We have usually found it desirable to filter agar media hot through a Millipore filter before use, though occasional batches have been obtained with which this expedient was not necessary. Blood agars were unsatisfactory because the corpuscles interfered with the phase contrast used for microscopic examination of the slides.

Inspection of slides. For bacteria and yeasts we have used a binocular microscope (magnification of $\times 360$; field diameter: $0.29-0.32 \mathrm{~mm}$.) with a $4 \mathrm{~mm}$. objective arranged for phase contrast in green light. A condenser with a working distance sufficient to focus through the slide and agar film is necessary; we have successfully used microscopes supplied by Messrs Cooke, Troughton and Sims Ltd. and by 
Messrs Watson Ltd. Mr R. E. Strange and his colleagues in this Establishment have used dark ground illumination satisfactorily. An objective having a long working distance is an advantage, since the slide may then be inspected without removing the coverslip, but fogging of the coverslip can be a nuisance and routinely we removed it for counts. Differential slides of pathogenic bacteria were sterilized by exposure to formaldehyde vapour before inspection.

Fields containing forty objects (dead bacteria or microcolonies) were usually chosen for counting, though with populations of low viability a larger number of objects per field was permissible. The microcolonies and dead organisms per field were counted separately. Sufficient whole fields, preferably adjacent, were counted to give a total of over 300 objects per slide studied. A tally counter or electric counting device is a great help in routine work of this kind. The viability was derived directly from the ratio of the number of microcolonies to the total number of microbial objects counted.

\section{RESULTS}

Aerobacter aerogenes (NCTC 417) obtained from Professor Sir Cyril Hinshelwood's laboratory was grown in continuous culture at $40^{\circ}$ and at a dilution rate of $0.2-$ $\mathbf{0 . 3} \mathrm{vol} . / \mathrm{hr}$. in a glycerol + salts medium resembling that used for Cloaca cloacae by Herbert et al. (1956) in which glycerol limited growth. Organisms were harvested in the logarithmic phase of growth, washed twice in a mixture of $0.137 \mathrm{M}-\mathrm{NaCl}$ (9 parts)

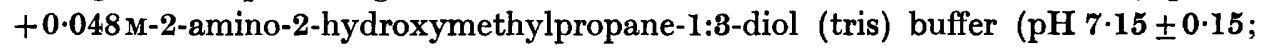
1 part) and incubated in this buffer at $40^{\circ}$ with gentle aeration to obtain moribund populations. In some experiments, for reasons unconnected with this paper, 0.316 mM ethylenediaminetetra-acetic acid (EDTA) was present. Data quoted refer to organisms harvested between the 250th and 1000th generations in continuous culture.

\section{Growth on slide cultures}

As a preliminary, some fresh or moribund populations were watched from shortly after inoculation until considerable multiplication of the viable bacteria had taken place. Records were kept of the behaviour of the individual organisms. The following points were established:

(i) When a large proportion of the bacteria were viable, microcolonies tended to over-grow the non-viable organisms. Hence fields containing more than 30-40 objects should be avoided.

(ii) In populations showing a high viability, all organisms that were going to divide had done so by the time the earliest starters had undergone two or three divisions. With moribund populations (less than $30 \%$ viability) the scatter of individual division lags was wider and more prolonged incubation was desirable.

(iii) Moribund populations contained a small proportion of organisms that appeared to attempt growth but to fail. They 'died' as drumstick-shaped or spherical bodies of low contrast. Such organisms were encountered most often in populations of intermediate (70-20\%) viability.

(iv) Loss of organisms owing to lysis was rare (usually a recognizable 'ghost' could be seen) and restricted to populations of less than $20 \%$ viability.

(v) Loss of organisms owing to lysis or overgrowth occurred most often when the average division lag was long. Hence media rich in nutrient supplements were 
desirable. In the case of Aerobacter aerogenes the medium of choice was that used for continuous culture of the organism supplemented with $0.1 \%(w / v)$ Difco yeast extract, $0 \cdot 1 \%(w / v)$ Difco Casamino acids, 1/10th volume of home-brewed tryptic meat broth and Difco agar to $1.5 \%(w / v)$. On this medium satisfactory differential counts were obtained after $2-4.5 \mathrm{hr}$. at $37^{\circ}$; moribund populations required the longer period of incubation.

\section{Evaluation of the method}

The reproducibility of the method with a population of bacteria dying 'naturally' was studied in the following manner. Organisms harvested from continuous culture at $40^{\circ}$ were washed twice in saline + tris buffer, suspended in distilled water to their original concentration and $1 \mathrm{ml}$. of this suspension added to four $50 \mathrm{ml}$. portions of saline +tris buffer. The population was then $c .5 \times 10^{7}$ organisms $/ \mathrm{ml}$. The tubes were incubated at $\mathrm{pH} \mathbf{7 \cdot 0} \pm \mathbf{0 \cdot 2}$ and $40^{\circ}$ with gentle aeration; one tube (A) was sampled at fairly frequent intervals during $10 \mathrm{hr}$., single differential counts being performed on the population. On some of these occasions tube $\mathbf{A}$ was tested in quadruplicate and then single differential counts on the other three tubes were also performed, thus providing blocks of seven tests on populations that should have had identical viabilities. These blocks of seven tests were performed in closely spaced pairs intended to bracket a high, a medium and a low viability of the population.

The counts were performed by three operators, none of whom 'specialized' in counting samples from a given suspension; each had his own microscope. On one occasion $(9 \mathrm{hr}$.) the operators re-counted each others' slides; Fig. 1 includes all the counts then obtained. The death curve of this population was essentially linear (Fig. 1); apparent tendencies to a sigmoid form suggested by inflexions during the first two and last hours fell within the $95 \%$ fiducial limits of the regression line and the death curve has been drawn without them. (Other experiments on this population indicated that the later inflexion was probably real.) Some of the data from which Fig. 1 was plotted are given in Table 1 . A $\chi^{2}$ test on the actual counts from which these data were obtained showed excellent agreement within each set of seven counts; the usual $95 \%$ fiducial limits of the regression line were $\pm 9 \cdot 2 \%$; the viabilities of the four suspensions did not tend to appear in any order during the $10 \mathrm{hr}$. of the experiment.

Comparison with a conventional viability determination. A second death curve was obtained by using ordinary plating-out procedures, combined with fourteen separate total counts by three operators on the initial population using two Thoma counting chambers of $0.03 \mathrm{~mm}$. depth. This procedure gave a mean population of $5.9 \times 10^{7} / \mathrm{ml}$. but in our hands the standard deviation of the technique was $\pm 1 \cdot 44 \times 10^{7}$ (counts by individuals showed greater reproducibility). Hence the error of the absolute viability from this source was $25 \%$ without taking account of errors in the platingout procedures. The experiment is illustrated in Fig. 2. The death curve obtained by the conventional procedures resembled that obtained by the differential procedure, but the viabilities were systematically lower. This difference is most likely due to errors in the total count; when viabilities were expressed as percentages of the initial plate count (taken as $97 \%$, the value indicated by the differential count), the death curves followed very similar courses. 
Table 2 illustrates some data obtained with a population which survived for a considerably longer period; there is close agreement between the differential count and the colony count, based on the assumption that the initial colony count represented $c .100 \%$ viability. These data were obtained in this laboratory by $\mathrm{Mr} \mathbf{R}$. Strange and his colleagues; as indicated in the legend, they refer to stationary phase Aerobacter aerogenes grown in conditions different from those used by ourselves.

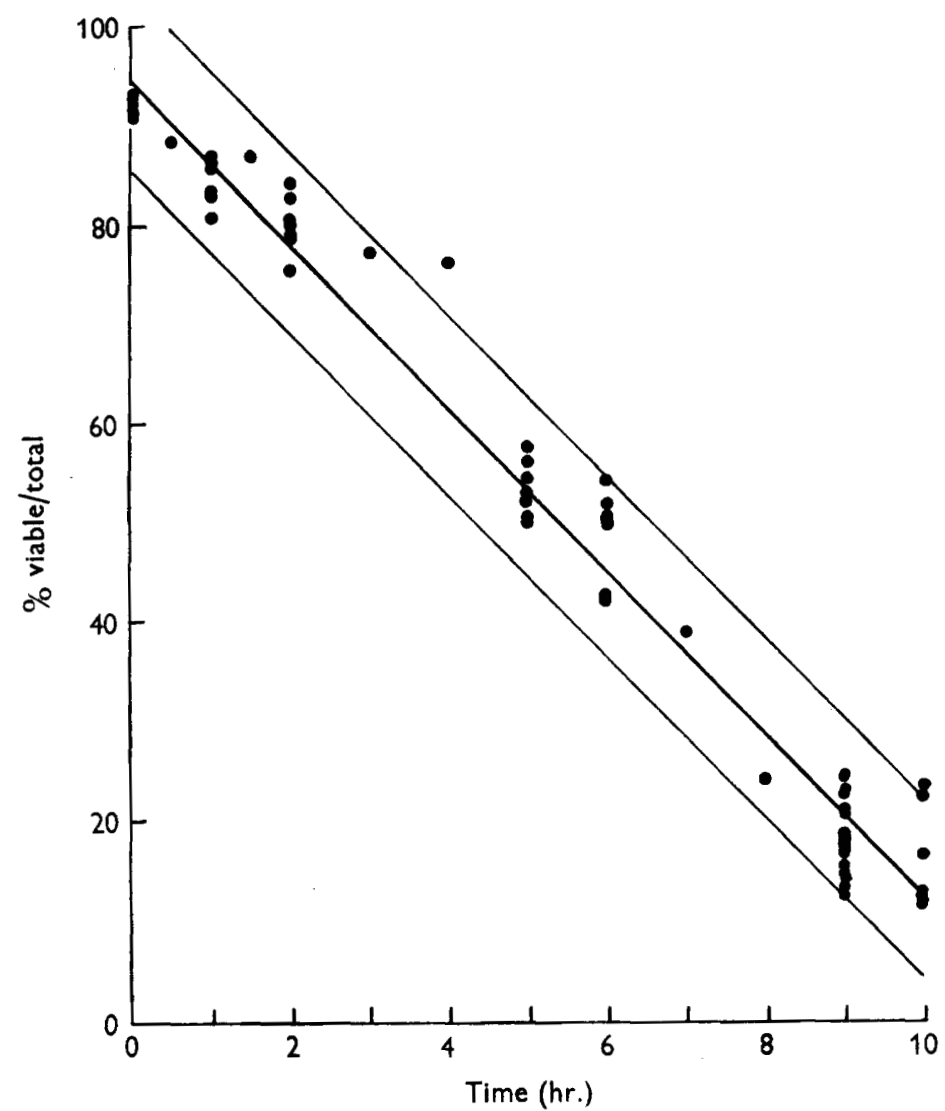

Fig. 1. Death curve of log phase Aerobacter aerogenes in aerated saline + tris buffer at $40^{\circ}$. Viabilities of four similar populations of $A$. aerogenes were determined by three operators using the differential counting procedure. For methods and sampling plan see text; for selected data see Table 1 .

\section{Various applications of the method}

Use with bactericides. The procedure provides a rapid method of determining the proportion of a population killed by a bactericide and may be used to follow the killing rate of such a compound, provided the kill can be expressed in percentages rather than powers of ten. Table 3 shows titrations of the immediate bactericidal effects of methylene blue, aureomycin and proflavine on Aerobacter aerogenes harvested in the logarithmic phase; Fig. 3 shows a death curve in which methylene blue exerted a delayed bactericidal effect even though its concentration was insufficient to show an immediate effect. 
Use with freeze-dried material. The procedure is useful for assessing the viability of suspensions before and after freeze-drying. A population of log phase Aerobacter aerogenes had a viability of $95 \cdot 1 \%$; after freeze-drying its viability was $4 \cdot 4 \%$ by a combination of conventional total and viable counts; $4.1 \%$ by the differential counting procedure.

Use with other micro-organisms. Several microbes have been grown on slides in the manner described to see whether their microcolonial appearance was suitable for use by the method. Those that were successful are listed, with the temperature of incubation and the incubation periods at which the differential count was clear and

Table 1. Representative sample of experimental material from which Fig. 1

$$
\text { was obtained }
$$

Viabilities of four similar dying populations of Aerobacter aerogenes were determined by three operators using the differential counting precedure. For methods and sampling plan, see text.

\begin{tabular}{|c|c|c|c|c|c|c|}
\hline $\begin{array}{c}\text { Time of } \\
\text { incubation } \\
(\mathrm{hr} .)\end{array}$ & $\begin{array}{c}\text { Population } \\
\text { tested } \\
(\mathbf{A}, \mathbf{B}, \mathbf{C} \text { or } \mathbf{D})\end{array}$ & $\begin{array}{l}\text { Micro- } \\
\text { colonies }\end{array}$ & $\begin{array}{c}\text { Dead } \\
\text { organisms }\end{array}$ & $\begin{array}{c}\text { Viability } \\
(\%)\end{array}$ & $\begin{array}{l}\text { Person } \\
\text { counting }\end{array}$ & $\begin{array}{c}\text { Time slide } \\
\text { culture was } \\
\text { incubated } \\
\text { (hr.) }\end{array}$ \\
\hline 0 & $\mathbf{A}_{1}$ & 292 & 26 & $91 \cdot 8$ & JRP & 2 \\
\hline 0 & $A_{2}$ & 280 & 21 & 93 & JRH & 2 \\
\hline 0 & $A_{3}$ & 289 & 21 & $93 \cdot 2$ & JRH & 2 \\
\hline o & $\mathbf{A}_{4}$ & 282 & 20 & 93.4 & JRH & 2 \\
\hline 0 & B & 285 & 29 & $90 \cdot 8$ & JEC & 2 \\
\hline o & C & 285 & 21 & $93 \cdot 1$ & JEC & 2 \\
\hline 0 & D & 301 & 24 & $92 \cdot 6$ & JRP & 2 \\
\hline 0.5 & $\mathbf{A}$ & 273 & 33 & $89 \cdot 2$ & JRH & 2 \\
\hline 1 & $\mathbf{A}_{1}$ & 300 & 44 & $87 \cdot 2$ & JRH & $2 \cdot 5$ \\
\hline 1 & $\mathbf{A}_{2}$ & 260 & 51 & $83 \cdot 6$ & JRP & $2 \cdot 5$ \\
\hline 1 & $A_{3}$ & 261 & 52 & $83 \cdot 4$ & JRH & 2.5 \\
\hline $\mathbf{1}$ & $\mathbf{A}_{4}$ & 269 & 43 & $86 \cdot 2$ & JRH & $2 \cdot 5$ \\
\hline 1 & B & 247 & 57 & $81 \cdot 2$ & JEC & 2.5 \\
\hline 1 & C & 279 & 44 & $86 \cdot 4$ & JRP & $2 \cdot 5$ \\
\hline 1 & D & 292 & 40 & $86 \cdot 6$ & JRH & $2 \cdot 5$ \\
\hline 1.5 & $\mathbf{A}$ & 274 & 40 & $87 \cdot 2$ & JRP & $2 \cdot 5$ \\
\hline 6 & $\mathbf{A}_{1}$ & 166 & 153 & 52 & JRP & $2 \cdot 5$ \\
\hline 6 & $\mathbf{A}_{2}$ & 144 & 196 & $42 \cdot 3$ & JRH & 2.5 \\
\hline 6 & $A_{3}$ & 156 & 150 & 50.9 & JEC & 2.5 \\
\hline 6 & $\mathbf{A}_{4}$ & 152 & 148 & $50 \cdot 6$ & JEC & $\begin{array}{l}2 \cdot 0 \\
2 \cdot 5\end{array}$ \\
\hline 6 & B & 144 & $\begin{array}{l}140 \\
194\end{array}$ & $\begin{array}{r}30 \cdot 0 \\
4,2 \cdot 6\end{array}$ & JRH & $\begin{array}{l}2.5 \\
2.5\end{array}$ \\
\hline 6 & C & 158 & 158 & 50 & JRP & 2.5 \\
\hline 6 & D & 172 & 143 & $54 \cdot 6$ & JRP & 2.5 \\
\hline 7 & $\mathbf{A}$ & 120 & 187 & $39 \cdot 1$ & JEC & 2.75 \\
\hline 8 & $\mathbf{A}$ & 75 & 236 & $24 \cdot 1$ & JEC & $2 \cdot 7$ \\
\hline
\end{tabular}

constant recorded in parentheses. Pseudomonas ovalis $\left(30^{\circ}\right.$; incubated for $2,3 \frac{1}{2} \mathrm{hr}$.), Serratia marcescens $\left(37^{\circ} ; 1 \frac{1}{4}, 2 \mathrm{hr}.\right)$, Pasteurella pestis $\left(28^{\circ} ; 4 \frac{1}{2}, 6 \mathrm{hr}.\right)$, Salmonella typhimurium ( $\left.37^{\circ} ; 2,3 \mathrm{hr}.\right)$, Micrococcus ' $\mathrm{M9}$ ' (37'; $\left.3 \frac{1}{2}, 5 \mathrm{hr}.\right)$, Bacillus subtilis $\left(37^{\circ}\right.$; $2,3 \mathrm{hr}$.), Alkaligenes metalcaligenes $\left(18-20^{\circ} ; 17,19 \mathrm{hr}\right.$.), bakers' yeast $\left(18-20^{\circ} ; 18\right.$, $22 \mathrm{hr}$.). All bacteria were tested in home-brewed tryptic meat agar; that for $\boldsymbol{P}$. pestis was supplemented with haematin. 'Viability' of the micrococcus was obtained as percentage viable units in the population because the strain showed many pairs and tetrads before incubation; hence the relatively long incubation periods. Bakers' yeast (pressed yeast from Distillers Co. Ltd.), which was grown on a medium containing malt extract, peptone, yeast extract and glucose, showed 
$91 \%$ viability on slide culture and $90 \%$ viability by the methylene blue vital staining procedure (Townsend \& Lindegren, 1953) when fresh; after 14 days in buffer at $\mathrm{pH} 7 \pm 0.3$ and room temperature the slide procedure gave a viability of $62 \%$ compared with $18.5 \%$ indicated by the methylene blue procedure. The procedure provided a rapid spore germination test with suspensions of $B$. subtilis, B. megaterium and B. cereus spores.

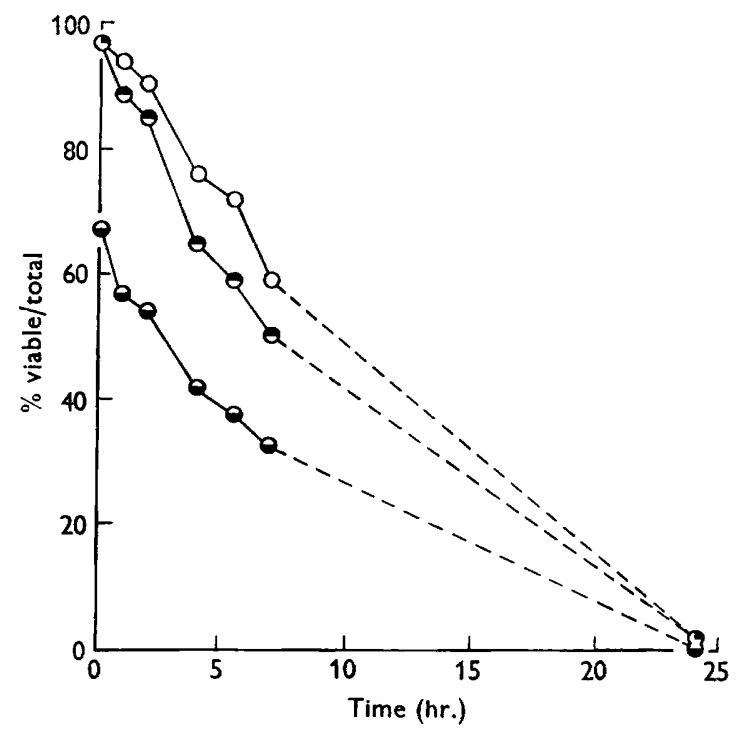

Fig. 2. Death curves of a population of log phase Aerobacter aerogenes obtained by conventional procedures and by slide culture. Logarithmic phase $A$. aerogenes were washed by centrifugation and incubated in saline + tris buffer containing a small amount of EDTA at $40^{\circ}$, pH 6.8 $\pm 0 \cdot 05$. Samples were removed at intervals for viability determinations (see text). $\odot \bar{C}$ onventional procedure; $O$ differential procedure; $\Theta$ colony counts as $\%$ initial colony count.

Table 2. Comparison between colony and differential counts on a population of Aerobacter aerogenes

A. aerogenes grown in tryptic meat broth and harvested after the population density had become stationary for $0.5 \mathrm{hr}$. were incubated with aeration at $37^{\circ}$ in $\mathrm{NaCl}$ $(0 \cdot 13 \mathrm{M})+\mathrm{KH}_{2} \mathrm{PO}_{4} / \mathrm{K}_{2} \mathrm{HPO}_{4}(0 \cdot 02 \mathrm{M}), \mathrm{pH} \mathrm{6 \cdot 50 \pm 0 \cdot 05}$.

$\begin{array}{lcccccccc}\text { Incubation period (hr.) } & 0 & 16 & \mathbf{2 4} & 40 & 48 & 64 & 72 & 88 \\ \text { Colony count } / 10^{-8} \mathrm{ml} . & 98 & 95 & 90 & 96 & 95 & 75 & 73 & 60 \\ \text { Differential count }(\%) & \mathbf{9 7 \cdot 5} & 98 & \mathbf{9 6} & 90 & 87 & 78 & 68 & 59\end{array}$

Organisms for which the method was not suitable were Escherichia coli type B $\left(37^{\circ} ; 1 \frac{1}{4}-3 \frac{1}{2} \mathrm{hr}.\right)$ and Bacillus megaterium $\left(c .37^{\circ}, c .2 \frac{1}{2} \mathrm{hr}\right.$.), both of which formed a mixture of ordinary cells and long ramifying filaments which obscured the slide.

\section{DISCUSSION}

The determination of viability directly by slide culture has certain obvious limitations. The method as described is limited to non-filamentous aerobes; bacteria with division lags longer than the incubation period are counted as dead; all organisms that have divided once are counted as live, even though both may occasionally be dead. The method is at its most exact at $50 \%$ viability, and is highly 
Table 3. Bactericidal effects of three inhibitors on Aerobacter aerogenes

Bacteria were harvested from continuous culture at $40^{\circ}$, washed twice and populations of c. $6 \times 10^{7}$ organisms $/ \mathrm{ml}$. exposed to bactericide solutions in saline + tris buffer $(\mathrm{pH} 7$ ), centrifuged and re-suspended in saline + tris buffer. The viable populations were then determined by slide culture. Exposure to inhibitor and centrifugation took about $10 \mathrm{~min}$. at room temperature. Controls without dye were also centrifuged.

\begin{tabular}{|c|c|c|}
\hline Bactericide & $\mu \mathrm{g} . / \mathrm{ml}$. & Viability ( \\
\hline \multirow[t]{6}{*}{ Methylene blue } & - & 90.7 \\
\hline & 5 & $82 \cdot 3$ \\
\hline & 10 & 55.9 \\
\hline & 20 & $39 \cdot 1$ \\
\hline & 40 & $7 \cdot 6$ \\
\hline & 80 & $1 \cdot 3$ \\
\hline \multirow[t]{5}{*}{ Proflavine } & 一 & $92 \cdot 9$ \\
\hline & 10 & $87 \cdot 4$ \\
\hline & 20 & $\mathbf{8 9 \cdot 3}$ \\
\hline & 40 & $82 \cdot 7$ \\
\hline & 80 & $62 \cdot 4$ \\
\hline \multirow[t]{6}{*}{ Aureomycin } & - & $96 \cdot 5$ \\
\hline & 10 & $91 \cdot 7$ \\
\hline & 20 & $94 \cdot 7$ \\
\hline & 40 & $86 \cdot 7$ \\
\hline & 80 & $56 \cdot 1$ \\
\hline & 100 & $\mathbf{3 9 \cdot 3}$ \\
\hline
\end{tabular}

insensitive at viabilities below, say, $5 \%$; errors due to overgrowth of dead organisms by microcolonies or to lysis on the agar film exist and may assume importance with organisms other than Aerobacter aerogenes. Moribund cultures often yield morphological aberrants and experience is needed to decide whether the organism is living,

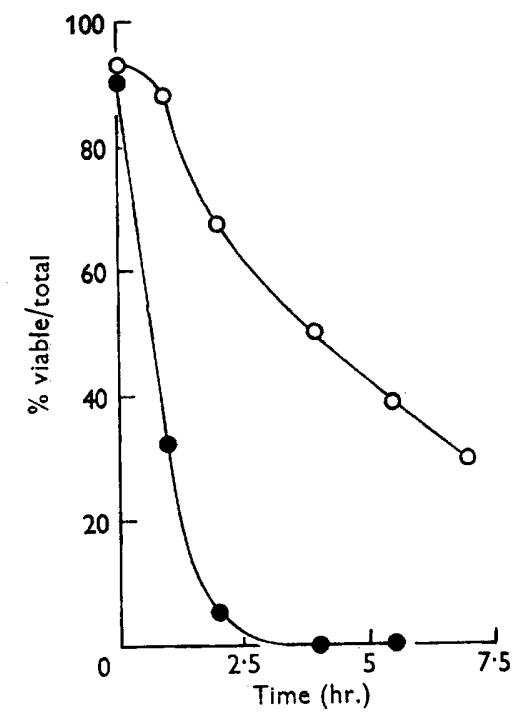

Fig. 3. Progress of bactericidal action of methylene blue on log phase Aerobacter aerogenes. Suspensions of c. $5 \times 10^{7}$ washed organisms/ml. saline +tris buffer containing EDTA aerated at $\mathrm{pH} 7 \cdot 05 \pm 0.05$ and $40^{\circ}$. $1 \mathrm{ml}$. samples were removed at intervals, washed once by centrifuging to remove inhibitor and the viabilities determined by slide culture. $\bigcirc$ Control; methylene blue, $5 \mu \mathrm{g} . / \mathrm{ml}$. 
dead, or a contaminant. The method has no obvious use in the counting of anaerobes; it cannot be used with populations totalling less than $c .10^{7}$ organisms $/ \mathrm{ml}$. Within these limitations, however, the method has one or two advantages. The operator has added confidence in the method because he actually sees the viable and nonviable organisms instead of deducing their presence from altered staining properties, permeability, dehydrogenase activity or refractive index. The ordinary determination of the ratio of total to colony counts is slow as well as being beset by two sets of experimental errors; it is probable that the differential count described here gives a considerably more accurate ratio provided the two counts fall within a tenfold range of each other. Finally, though it is probably inferior in accuracy to other methods based on direct observation of growth of individual organisms (Valentine \& Bradfield, 1954; Powell, 1956), it requires considerably less specialized apparatus.

The authors are indebted to $\mathrm{Mr}$ S. Peto and his colleagues for statistical examinations of their data, and to Mr R. Strange for permission to use some of his unpublished data.

\section{REFERENCES}

Barer, R., Ross, K. F. A. \& Tkaczyk, S. (1953). Refractometry of living cells. Nature, Lond. 171, 720.

Firkhman, B. A. (1959). The prineiples of immersion micro-refractometry for a direct determination of live and dead bacterial cells. C.R. Acad. Sci., U.S.S.R. 124, 1141.

Greenberg, L., Eidus, L. \& Diena, B. B. (1958). The vital staining method for the rapid estimation of the bacterial count of B.C.G. vaccine. Amer. Rev. Tuberc. 78, 785.

Herbert, D., Elsworth, R. \& Telling, R. C. (1956). The continuous culture of bacteria; a theoretical and experimental study. J. gen. Microbiol. 14, 601 .

KNAYSI, G. (1935). A microscopic method of distinguishing dead from living bacterial cells. J. Bact. 30, 193.

KNAYSI, G. \& ForD, M. (1938). A method of counting viable bacteria in milk by means of the microscope. J. Dairy Sci. 21, 129.

KNöLL, H. (1944). Zur Anwendung der Phasenkontrastmikroskopie in der Bakteriologie. Zeiss Nachr. 5, 38.

Kосн, A. L. (1959). Death of bacteria in growing culture. J. Bact. 77, 623.

Mager, J., Kuczynski, M., SchatzBerg, G. \& Avi-Dor, Y. (1956). Turbidity changes in bacterial suspensions in relation to osmotic pressure. J. gen. Microbiol. 14, 69.

Powell, E. O. (1956). A rapid method for determining the proportion of viable bacteria in a culture. J. gen. Microbiol. 14, 153.

Razumovskaya, Z. G. \& Osipova, I. V. (1958). The ratio between live and dead bacteria in a multiplying culture of Acetobacter melanogenum. Microbiologiya, 27, 727.

STRUGGer, S. (1948). Fluorescence microscope examination of bacteria in soil. Canad. $J$. Res. 26, 188.

Taubeneck, U. (1957). Die Herstellung von Formvar-Netzfolien und ihre Verwendung für Mikrokulturen. Z. Bakt. (1), 168, 627 .

TAUBENECK, U. (1959). New grid-replica for precise localization in slide culture. J. Bact. 77, 506.

Townsend, G. F. \& Lindegren, C. C (1953). Structures in the yeast cell revealed in wet mounts. Cytologia, Tokyo, 18, 183.

VAlentine, R. C. \& Bradfieid, J. R. G. (1954). The urea method for bacterial viability counts with the electron microscope and its relation to other viability counting methods. J. gen. Microbiol. 11, 349.

Wade, H. E. \& Morgan, D. M. (1954). Differentiation of growing and non-growing bacteria by a staining technique. Nature, Lond. 174, 020.

WhITE, P. B. (1947). A method for combined positive and negative staining of bacteria. J. Path. Bact. 59, 334. 
24 J. R. Postgate, J. E. Crumpton and J. R. Hunter

EXPLANATION OF PLATES

\section{Plate 1}

Slide cultures for differential counts in preparation. The right-hand annulus contains agar but has not been covered. The left-hand annulus has been covered with a coverslip and is in process of being sealed with water from a loop.

\section{Plate 2}

Photomicrograph of the surface of a slide culture of a moribund population of Aerobacter aerogenes. The population from which this slide was prepared had been harvested in the logarithmic phase of growth, washed by centrifugation and aerated for $1 \mathrm{hr}$. in saline + tris buffer with Versene at $40^{\circ}$, pH 7.05 \pm 0.05 . A portion was then incubated as a slide culture for $3.5 \mathrm{hr}$. Viability: $68 \%$. Phase contrast; magnification $\times 800$. 
Journal of General Microbiology, Vol. 24, No. 1

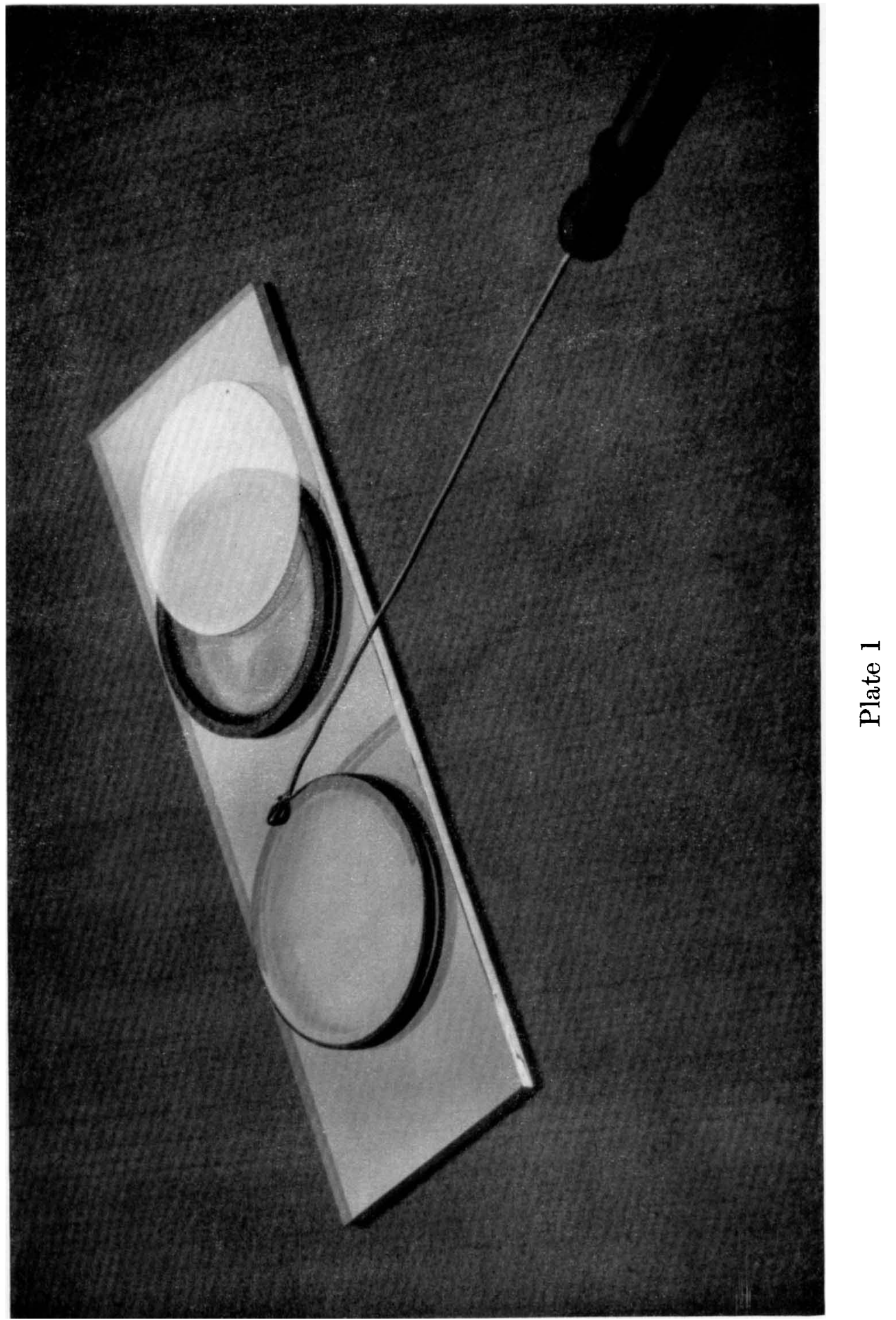


Journal of General Microbiology, Vol. 24, No. 1

Plate 2

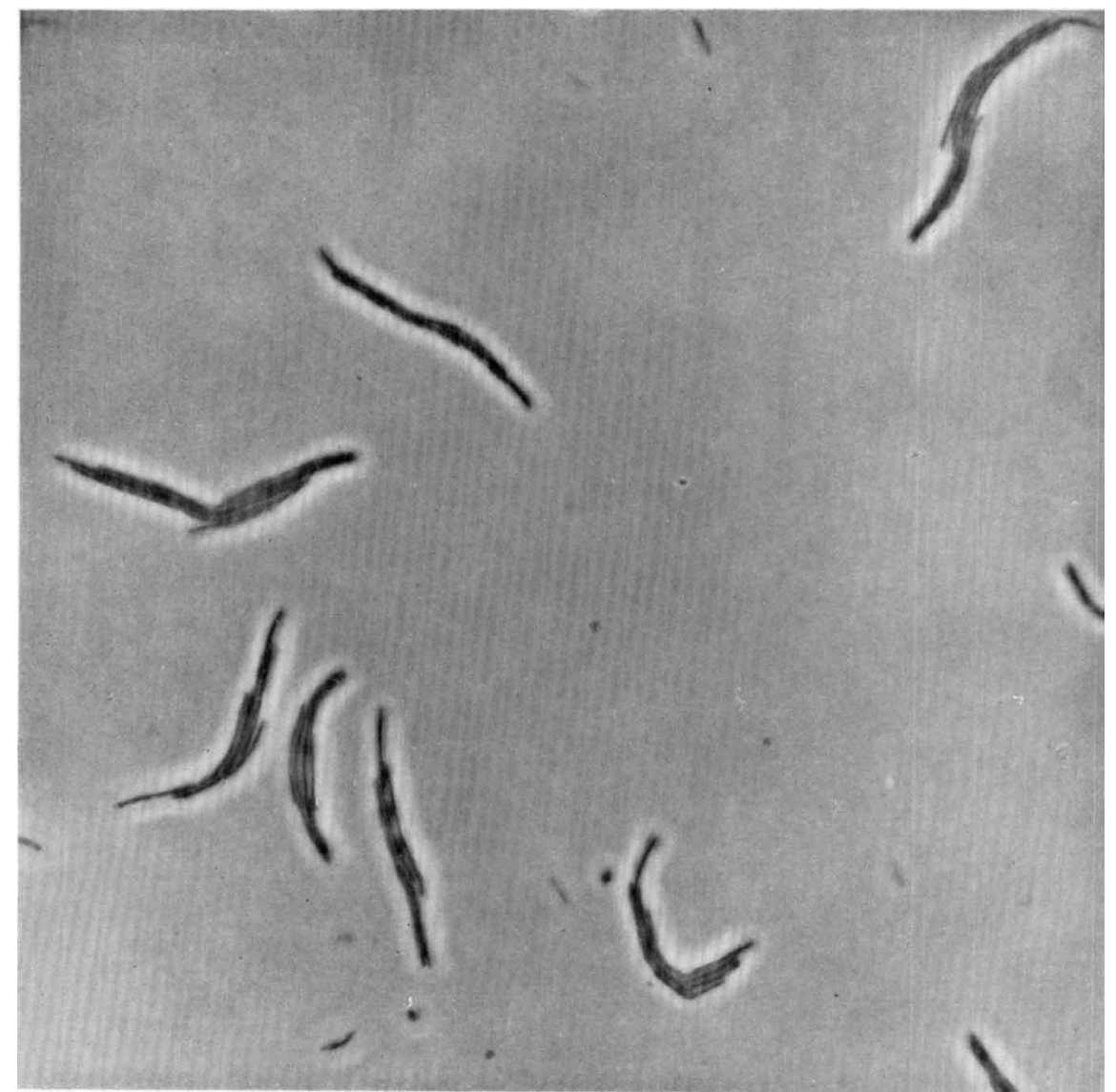

J. R. POSTGate, J. E. CRUMPTON AND J. R. HUN'TER 